Egyptian Journal of Rabbit Science, 27 (2): 197- 217 (2017)

\title{
UTILIZATION OF POMEGRANATE (Punica granatum L.) BY- PRODUCT POWDER AS A NATURAL GROWTH PROMOTER IN GROWING RABBIT DIETS.
}

\author{
M. R. M. Ibrahim ${ }^{I}$; Sohair A. Arafa ${ }^{1}$; Fawzia A. Hassan ${ }^{2}$ and Eman E. Zaki \\ ${ }^{1}$ Department of Animal Production, Faculty of Agriculture, Cairo University, Giza, Egypt. \\ ${ }^{2}$ Animal Production Research Institute, Agricultural Research Center, 12618. El- \\ Dokki,Giza, Egypt. $\quad{ }^{*}$ Corresponding author: fawzia amer@yahoo.com
}

The study was conducted to evaluate the effects of using pomegranate (Punica granatum L.) by-product powder (PBP) as a natural growth promoter in rabbit diets on growth performance. A total of 36 male New Zeeland White (NZW) rabbits was randomly assigned to four groups containing 9 rabbits each in 3 replicates and raised from 5 to 13 weeks of age and nearly equal average initial live body weight (561.67 \pm $6.68 \mathrm{~g})$. The experimental groups, the first group was fed basal diet control without PBP as control, while the second, third and fourth groups were supplemented with 1.0, 1.5 and $2.0 \%$ of PBP, respectively.

The obtained results demonstrated that rabbits fed diet supplemented with $1.5 \%$ of PBP had the heaviest $(P<0.05)$ final body weight and average daily weight gain followed by those received 2.0, $1.0 \%$ and control groups. Rabbit groups fed diets supplemented with 1.0, 1.5 or $2.0 \%$ PBP recorded significantly $(P<0.05)$ higher digestibility of DM, OM, CP, and CF compared to the control group. Besides, the digestibility of DM, OM, CP,CF and NFE were higher $(P<0.05)$ with rabbits group fed diet supplemented with $2.0 \%$ PBP than the other tested groups. Moreover, data of nutritive values illustrated that rabbit group fed $1.5 \%$ or $2.00 \% P B P$ recorded the highest $(P<0.05)$ values of DCP, TDN and DE compared to the other tested groups. Supplementation of PBP had no effect on meat CP content. While, there were significantly $(P<0.05)$ decrease in EE meat content of rabbits group fed diet supplemented with 1.0 and $2.0 \%$ of $P B P$ than the control group. The supplementation of PBP increased $(P<0.05)$ plasma total protein, albumin and globulin levels compared to those of rabbits fed the control diet. The blood plasma content of glucose, total lipids, total cholesterol and LDL was observed to move down constant 
with increasing dietary levels of $P B P(1.0,1.5$ and $2.0 \%)$, respectively. Also, the values of T-AOC, SOD, CAT and GSH-Px were significantly $(p<0.05)$ increased with increasing PBP levels in rabbit diets. Additionally, rabbits fed $1.5 \%$ PBP diet recorded the best net revenue.

Conclusively, the results suggest that the pomegranate (PBP) byproduct powder could be supplied in rabbit diets at $1.5 \%$ to achieve best performance and economical efficiency without any adverse effect on rabbit's heath.

Key words: Pomegranate by-products, NZW rabbit, growth promoter, digestibility

In the recent years, more attention was tended to use natural feed additives for rabbits, poultry and livestock. Pomegranate (Punica granatum L.) is a widely spread fruit crop in the Mediterranean region, especially Egypt. In Egypt, about 43605 Acres are cultivated with pomegranate (punica granatum L.), which produce about 18.825 ton/acre. Besides, the production reached to approximately 132031 tons (Ministry of Agriculture, 2014). At present, research on the effect of pomegranate by-products in animal feeding is widely interested in the inclusion of pomegranate by-products as fresh peel (Shabtay et al., 2008), seeds (Modaresi et al., 2011), extract additives (Oliveira et al., 2010; Shabtay et al., 2012) or peel and seed silage (Kotsampasi et al.,2014) in ruminant's diet. Pomegranate by-products constitute approximately $52 \%$ of the total weight of fruit, which remain after the processing of pomegranate for juice concentrates (Saki et al. 2014).

Several studies have shown that pomegranate by-product is an important source of bioactive compounds such as phenolic compounds, which are known as secondary plant metabolites and possess antiinflammatory, anti-therosclerotic, antitumor, antimutagenic, anticarcinogenic, antibacterial, or antiviral activities, however, its use remained very limited and traditional (Abdel Motaal and Sherif, 2011; Cai et al., 2004; Li et al., 2006, Ali, 2012 and Zeweil et al. 2013).

Recent studies have found that pomegranate by-products may have the potential to be a good source of nutrients and antioxidants for livestock feeding, such as rabbits (Zeweil and El-Gindy, 2016); Moreover, the antioxidant potential of pomegranate in vivo and in vitro has been proved (Singh et al., 2002). 
Therefore, the objective of the current study was to evaluate the effect of supplementation of pomegranate by-products powder as a natural growth promoter in NZW rabbit diets on some growth performance traits, nutrients digestibility, carcass characteristics and blood parameters, as well as, and economical efficiency (\%), under Egyptian conditions.

\section{MATERIALS AND METHODS}

The experimental work of this study was carried out at Private Rabbitary Farm, Kalyubia Governorate, during the period from April till June 2016.

\section{Experimental design and management}

Thirsty six of weaned New Zealand White (NZW) male rabbits at 5 weeks of age and nearly equal averages initial live body weight (561.67 \pm $6.68 \mathrm{~g}$ ) were randomly assigned to four experimental treatment groups (9 rabbits/ group) each in 3 replicates ( 3 rabbits for each) in a complete simple randomized design. The first experimental group received daily untreated pelleted diet as control group. The second, third and fourth experimental groups received daily pelleted diet supplemented with $1.0,1.5$ and $2 \%$ of pomegranate by-product powder (PBP), respectively. The experimental period lasted for 8 weeks. Pomegranate by-product was obtained from Fontana Company (Food Industries, Kalyubia Governorate, Egypt).

Rabbits were individually housed in galvanized wire cages (Dimensions of $60 \times 40 \times 35 \mathrm{~cm}$ ) until marketing at 14 weeks of age, under a 12:12 h light-dark cycle. All rabbits were fed pelletized feed ad libitum, fresh water was automatically available all the time by stainless steel nipples fixed in each cage. The rabbits were reared in a well-ventilated building. All rabbits were kept under the same management, hygienic and environmental conditions.

\section{Experimental animals and diets}

Feed ingredients and chemical composition of experimental diets (\%DM basis) are shown in Table 1. The experimental diets were formulated to meet the recommended nutrient requirements of growing rabbits according to Lebas (2013). 
Table 1: Feed ingredients and chemical composition of experimental diets (\% DM basis).

\begin{tabular}{|c|c|c|c|c|}
\hline \multirow{2}{*}{ Items } & \multirow{2}{*}{ Control } & \multicolumn{3}{|c|}{ Experimental diets (\%) } \\
\hline & & $\begin{array}{c}\text { PBP } \\
(\mathbf{1 . 0 \%})\end{array}$ & $\begin{array}{c}\text { PBP } \\
(1.5 \%)\end{array}$ & $\begin{array}{c}\text { PBP } \\
(2.0 \%)\end{array}$ \\
\hline \multicolumn{5}{|l|}{ Feed Ingredients (\%) } \\
\hline Yellow corn & 13.70 & 12.70 & 12.20 & 11.70 \\
\hline Soybean meal (44\% CP) & 15.00 & 15.00 & 15.00 & 15.00 \\
\hline Barley & 25.00 & 25.00 & 25.00 & 25.00 \\
\hline Wheat bran & 12.00 & 12.00 & 12.00 & 12.00 \\
\hline Clover hay & 30.00 & 30.00 & 30.00 & 30.00 \\
\hline Molasses & 3.00 & 3.00 & 3.00 & 3.00 \\
\hline $\mathrm{NaCl}$ & 0.30 & 0.30 & 0.30 & 0.30 \\
\hline $\operatorname{Premix}^{\mathrm{a}}$ & 0.30 & 0.30 & 0.30 & 0.30 \\
\hline Di-Ca-phosphate & 0.30 & 0.30 & 0.30 & 0.30 \\
\hline DL-Methionine & 0.40 & 0.40 & 0.40 & 0.40 \\
\hline Pomegranate by-products (PBP) & 0.00 & 1.00 & 1.50 & 2.00 \\
\hline Total & 100 & 100 & 100 & 100 \\
\hline \multicolumn{5}{|l|}{ Chemical composition (\%DM basis) } \\
\hline DM & 91.02 & 91.37 & 91.18 & 91.18 \\
\hline $\mathrm{OM}$ & 91.42 & 90.77 & 90.68 & 90.59 \\
\hline $\mathrm{CP}$ & 17.18 & 17.21 & 17.22 & 17.29 \\
\hline $\mathrm{CF}$ & 13.71 & 13.92 & 14.10 & 14.43 \\
\hline $\mathrm{EE}$ & 3.81 & 3.77 & 3.76 & 3.73 \\
\hline NFE & 56.72 & 57.87 & 55.60 & 55.14 \\
\hline Ash & 8.58 & 9.23 & 9.320 & 9.410 \\
\hline Methionine & 0.63 & 0.63 & 0.63 & 0.63 \\
\hline Lysine & 0.80 & 0.79 & 0.79 & 0.79 \\
\hline Calcium & 0.84 & 0.83 & 0.83 & 0.83 \\
\hline Available phosphorus & 0.31 & 0.31 & 0.31 & 0.31 \\
\hline Digestible energy $(\mathrm{Kcal} / \mathrm{Kg} \mathrm{DM})^{\mathbf{b}}$ & 2784 & 2774 & 2770 & 2770 \\
\hline
\end{tabular}

${ }^{a}$ Mineral and vitamin mixture supplied per kg of diet: Vitamin A 10,000 IU, Vitamin D3,1,800 UI; Vitamin E, $15 \mathrm{mg}$; vitamin K3, $4.5 \mathrm{mg}$; Vitamin B1, $0.5 \mathrm{mg}$; Vitamin B2, 4 $\mathrm{mg}$; Vitamin B12, $0.001 \mathrm{mg}$; Folic acid, $0.1 \mathrm{mg}$; Pantothenic acid, $7 \mathrm{mg}$; Nicotinic acid, 20 mg; I, $1 \mathrm{mg}$; Mn, $60 \mathrm{mg}$; Cu, $5.5 \mathrm{mg}$, Zn, $75 \mathrm{mg}$; Fe, $40 \mathrm{mg}$; Co, $0.3 \mathrm{mg}$; Se, $0.08 \mathrm{mg}$.

${ }^{b}$ Digestible energy (DE) was calculated according to Lebas (2013)

Chemical analysis of pomegranate by-products (Punica granatum L.) powder and experimental diets were detected according (AOAC, 2007) as shown in Table 2. The chemical analysis and the fraction of phenolic and flavonoids compounds of pomegranate by-products powder were presented in Tables 2. 
Table 2. Chemical analysis of pomegranate by-products powder (on DM basis).

\begin{tabular}{cccccccccc}
\hline $\begin{array}{c}\text { Items } \\
(\%)\end{array}$ & DM & OM & CP & CF & EE & NFE & Ash & $\begin{array}{c}\text { Total } \\
\text { phenols } \\
(\%)\end{array}$ & $\begin{array}{c}\text { Total } \\
\text { Flavonids } \\
(\%)\end{array}$ \\
\hline $\begin{array}{c}\text { Pomegranate } \\
\text { by-products } \\
\text { powder (PBP) }\end{array}$ & 88.74 & 87.20 & 10.21 & 19.71 & 2.87 & 54.41 & 12.80 & $1.72 \%$ & $0.21 \%$ \\
\hline Yellow corn & 88.00 & 98.60 & 7.7 & 2.3 & 3.8 & 84.80 & 1.40 & - & - \\
\hline
\end{tabular}

Analyzed according to AOAC (2007).

Flavonids and phenolics were determined in Micro Analysis Lab., Food Technology Research Institute by A high-performance liquid chromatographic (HPLC).

A digestibility trial was conducted to determine the nutrient digestion coefficients and the nutritive value of the experimental diets according to (Perez et al.. 1995). Twelve male New Zealand White rabbits were used in a digestibility trial and allotted randomly to four groups of three rabbits each. Rabbits were housed in individual metabolism cages and fed the experimental diets for a period of 7 days (preliminary period) for adaptation then faeces were collected every 24 hours for 5 consecutive days (collection period). Samples of daily faeces of each rabbit were taken and oven dried at $70^{\circ} \mathrm{C}$ for $48 \mathrm{~h}$, then samples were ground and stored for proximate chemical analysis. Samples of feed and dried faeces were analyzed for dry matter $(\mathrm{DM})$, crude protein $(\mathrm{CP})$, ether extract (EE), crude fiber (CF), and ash according to (AOAC, 2000). The nutritive values of the experimental diets expressed as DCP and TDN were calculated according to Cheeke et al. (1982). Digestible energy (DE, Kcal/Kg diet) was calculated as follows: TDN $\times 44.3$ according to (Schneider and Flatt, 1975).

Pomegranate by-products, which include defective fruits, skins, seeds and peels, in wet form with moisture content of $60-65 \%$. So, they were dried by sun-drying to $9-10 \%$ moisture, then ground by hammer mill and were kept for subsequent processing.

Live body weight was determined weekly throughout the experimental period, and weight gain was calculated. Feed consumption was determined precisely and calculated as grams per rabbit per day, during the all experimental period. Unused feed from each cage was collected daily, weighed 
and taken into consideration for the calculation of feed consumption, accordingly, feed conversion was easily calculated (g feed / g gain).

\section{Slaughtering and carcass characteristics}

At the end of the experimental period (14 weeks old), five male rabbits from each group were randomly taken, fasted for 12 hours, individually weighed and immediately slaughtered. Slaughter procedure and carcass analysis were carried out as described by Blasco and Ouhayoun (1996). After complete bleeding, pelt, viscera's and tail were removed then the carcass and its components were weighed as an edible parts. The non edible parts including lung, spleen, stomach, large intestine, small intestine and kidney fat were also weighed as percentage of pre-slaughter weight. Dressing percentage was calculated by dividing the hot dressed carcass weight by preslaughter weight and expressed as a percentage.

\section{Determination of biochemical parameters}

Thirty five blood samples (5 ml from each rabbit) were collected during slaughtering and centrifuged at 3000 r.p.m. for 15 minutes to separate blood plasma. Plasma total protein, albumin, glucose, total cholesterol, LDL, HDL-cholesterol, total lipids, and creatinine were colormetrically determined using commercial kits (purchased from Bio-diagnostic, Egypt), according to the manufacturers' instructions. Plasma globulin concentration was calculated by difference and Albumin/Globulin ratio was calculated. Blood antioxidant constituents were assayed by colorimetric technique using commercial kits (Biodiagnostic, Egypt). Blood plasma malondialdehyde (MDA) and glutathione peroxidase (GPx) activity were assayed using the method of Chiu et al., (1976). Superoxide dismutase (SOD) activity was assayed according to Misra and Fridovich (1972). Total antioxidant capacity (T-AOC) was determined according to Koracevic et al. (2001) and catalase (CAT) activity was measured according to Aebi (1984).

\section{Economical efficiency (\%)}

To determine the economical efficiency of the experimental diets for body weight gain, the costs of feed required for producing one $\mathrm{kg}$ of body weight gain was calculated. The cost of the experimental diets was calculated according to the price of different ingredients prevailing at local market, as well as, the price of tested materials at the time of experimentation. 
Economical efficiency (\%) was calculated as a ratio between the return of weight gain and the cost of consumed feed.

\section{Statistical analysis}

The obtained data were statistically analyzed using the general linear model procedure of SAS® Software Statistical Analysis (SAS, 2002). All results were analyzed using this model according to as follows:

$$
\mathrm{Yij}=\mu+\mathrm{Ti}+\mathrm{eij}
$$

Where: Yij= the observation of $\mathrm{ij} ; \mu=$ Overall mean; $\mathrm{Ti}=$ Effects of $\mathrm{i}$ (treatments) and eij= Experimental random error.

Differences among means were tested by Duncan's multiple range test (Duncan, 1955).

\section{RESULTS AND DISCUSSION}

\section{Chemical analysis of pomegranate by-product powder}

The chemical composition of the PBP was examined and presented in Table 2. Crude protein content of PBP was $10.21 \%$ was being similar to that reported by Zeweil et al. (2013) being $10.06 \%$. However, EE content (2.87\%) in pomegranate by-products powder was lower than that reported by Zeweil et al. (2013) being $(2.40 \mathrm{~g} / \mathrm{kg} \mathrm{DM})$. In addition, PBP had a higher CF content (19.71\% vs. $11.43 \%)$. In this connection, Zeweil and El-Gindy (2016) reported that pomegranate peel contained 90.00, 82.12, 9.61, 2.35, 13.07, 57.09 for dry matter, organic matter, crude protein, ether extract, crude fiber, nitrogen free extract.

Natural antioxidants including phenolic compounds may act to confer an effective defense system against free radical attack. The amount of total phenols was $1.72 \%$ and total flavonids was $0.21 \%$. In this connection. Zeweil et al. (2016) stated that the total phenolic content of pomegranate peel was 272 mg GAE /g DM. Moreover, Azoz and Basyony (2012) reported that total phenolic content was $270 \mathrm{mg}$ GAE / g Dry weight of this pomegranate by-product.

\section{Growth performance traits}

Results of some growth performance traits are presented in Table 3. The obtained results demonstrated that rabbits fed diet supplemented with1.5\% of PBP had the heaviest $(\mathrm{P}<0.05)$ final body weight $(2161.5 \mathrm{~g})$ and average daily weight gain ( $28.46 \mathrm{~g} / \mathrm{rabbit} /$ day) at the whole period (5-12 
Table (3). Growth performance of growing rabbits fed experimental diets containing different levels of pomegranate by-product powder (PBP) from 5-12 weeks of age.

\begin{tabular}{|c|c|c|c|c|c|}
\hline \multirow[b]{2}{*}{ Items } & \multicolumn{4}{|c|}{ Experimental diets (\%) } & \multirow[b]{2}{*}{ \pm SEM } \\
\hline & $\begin{array}{c}\mathbf{0 . 0} \\
\text { Control }\end{array}$ & $\begin{array}{c}1.0 \\
\text { PBP }\end{array}$ & $\begin{array}{c}1.5 \\
\text { PBP }\end{array}$ & $\begin{array}{l}2.0 \\
\text { PBP }\end{array}$ & \\
\hline No. of Rabbits & 9 & 9 & 9 & 9 & \\
\hline Initial body weight (g/rabbit) & 567.0 & 566.50 & 568.0 & 567.0 & 45.17 \\
\hline Final body weight (g/rabbit) & $1988.0^{\mathbf{b}}$ & $2067.5^{\mathrm{ab}}$ & $2161.5^{\mathrm{a}}$ & $2143.0^{\mathbf{a}}$ & 47.86 \\
\hline \multicolumn{6}{|c|}{ Average daily weight gain (g/rabbit/day) } \\
\hline Weeks 5-8 & 28.37 & 28.43 & 30.77 & 30.14 & 1.21 \\
\hline Weeks 9-12 & $22.78^{\mathbf{b}}$ & $25.17^{\mathbf{a b}}$ & $26.14^{\mathrm{a}}$ & $26.43^{\mathrm{a}}$ & 1.09 \\
\hline Weeks 5-12 & $25.58^{\mathrm{b}}$ & $26.80^{\mathrm{ab}}$ & $28.46^{\mathrm{a}}$ & $28.28^{\mathrm{a}}$ & 0.65 \\
\hline \multicolumn{6}{|c|}{ Average daily feed intake (g/rabbit/day) } \\
\hline Weeks 5-8 & $76.96^{\mathbf{b}}$ & $76.59^{\mathbf{b}}$ & $80.59^{\mathrm{a}}$ & $80.16^{\mathbf{b}}$ & 0.77 \\
\hline Weeks 9-12 & $92.44^{\mathrm{ab}}$ & $90.39^{\mathbf{b}}$ & $90.89^{\mathbf{b}}$ & $94.79^{\mathrm{a}}$ & 1.08 \\
\hline Weeks 5-12 & $94.94^{\mathbf{b}}$ & $95.39^{b}$ & $95.89^{\mathbf{b}}$ & $99.79^{a}$ & 0.83 \\
\hline \multicolumn{6}{|c|}{ Feed conversion (g feed/g gain) } \\
\hline Weeks 5-8 & 2.71 & 2.69 & 2.62 & 2.66 & 0.12 \\
\hline Weeks 9-12 & $4.06^{\mathrm{a}}$ & $3.59^{\mathrm{ab}}$ & $3.47^{\mathrm{b}}$ & $3.58^{\mathrm{ab}}$ & 0.21 \\
\hline Weeks 5-12 & $3.71^{\mathrm{a}}$ & $3.55^{\mathrm{ab}}$ & $3.36^{\mathrm{b}}$ & $3.52^{\mathrm{ab}}$ & 0.18 \\
\hline
\end{tabular}

a, $\mathbf{b}$, Mean values with the same letter within the same row did not differ significantly $(\mathrm{P}>0.05)$.

weeks), followed by those received 2.0, $1.0 \%$ and control groups, respectively. However, body weight gain at (5-9 weeks) and (9-13 weeks) were not affected $(\mathrm{P}<0.05)$ by PBP supplementation among tested levels.

The results of the present study clearly indicated that dietary supplementation of different levels of PBP had a positive effect on growth performance of growing rabbits. The improvement in body weight gain was due to that pomegranate by-product is an important source of bioactive compounds, such as flavonoids, phenolic acids, diterpenes, saponins and tannis and it possess anti-inflammatory, anti-therosclerotic, antitumor, antimutagenic, anticarcinogenic, antibacterial, or antiviral activities (Abdel Motaal and Sherif, 2011; Cai et al., 2004; Li et al., 2006). In addition, these compounds have received much attention for their high antioxidative activity by scavenging free radicals which cause oxidative stress that can lead to cellular damage (Lampe, 1999; Al-Moraie et al. 2013). 
Concerning the feed intake, the obtained results showed that rabbits group fed $1.5 \%$ PBP diet consumed higher $(\mathrm{P}<0.05)$ amount as compared the other treated groups during the first period (5-8 weeks old). While, rabbits group fed 2.0\% PBP diet consumed higher $(\mathrm{P}<0.05)$ amount compared to the other tested groups during both the second period (5-8 weeks old) and the whole period (5-12 weeks old). These results are in agreement with those of Azoz and Basyony (2012) who observed that rabbits fed diets supplemented with dried pomegranate waste at $0.5,1.0$ and $1.5 \%$ levels were higher $(\mathrm{P}<0.01 \& \mathrm{P}<0.05)$ in feed intake than the control group. Besides, Mady et al. (2016) found that rabbits fed diets supplemented with 5, 10 and $15 \%$ of pomegranate peel recorded the highest values of daily weight gain and feed intake compared to the control group. On contrary, Fayed et al. (2012) demonstrated that diets containing $0.5,1.0$ and $1.5 \%$ pomegranate peel reduced total feed intake and also live body weight of rabbits at the end of the experiment.

Supplying rabbit diets with PBP at each treated level resulted in an improvement in FCR when compared to the control group during the different experimental periods. The obtained results also, revealed that rabbits group fed 1.5\% PBP diet recorded better $(\mathrm{P}<0.05)$ FCR than that of the control group during the second and whole periods. The results herein are somewhat agree with those reported by Bostami et al. (2015) who concluded that supplying Ross broilers diets with fermented pomegranate by-products at $0.5,1.0$ and $2 \%$ could improve growth performance.

Improvements in feed conversion ratio of the PBP diets as compared to the control group, may be due to the biological function of pomegranate fruits by-products; peels and seeds, powder, which have much higher exceptionally content of lysine, isoleucine and amino acids containing sulpher (Methionine and Cysteine), which are usually deficient in the most feedstuffs (Rowayshed et al., 2013). The possible reasons may be attributed to the use of polyphenols limit lipoperoxidation and preserve animal health (Georgiev et al., 2014) also, natural antioxidants can protect the intestinal mucosa against oxidative damage and pathogens and limit peristaltic activity in digestive disorders preventing diarrhea (Kermauner and Laurenčič, 2008). It could be suggested that dietary supplementation of (PBP) may be useful to improve health and overall growth performance in growing rabbits. 


\section{Digestibility and nutritive value of the experimental diets}

Results in Table (4) showed that rabbit groups fed diets supplemented with $1.0,1.5$ or $2.0 \%$ PBP recorded significantly $(\mathrm{P}<0.05)$ higher digestibility of DM, OM, CP, and CF compared to the control group. Besides, the digestibility of DM, OM, CP, CF and NFE were higher $(\mathrm{P}<0.05)$ with rabbits group fed diet supplemented with 2.0\% PBP than the other treatment groups. Meantime, insignificant differences in EE digestibility were observed among rabbits groups fed 1.0, 1.5 or $2.0 \%$ PBP diets and control group. These results disagreed with those reported by Fayed et al. (2012) who stated that supplementation of $0.5,1.0$ and $1.5 \%$ pomegranate peel in rabbit diets had lower digestible nutrients \% (CP, EE, and NFE), while pomegranate peel $1.5 \%$ improved $\mathrm{CF}$ digestibility compared with the control group. On the other hand, data of nutritive values illustrated that rabbit group fed $1.5 \%$ or $2.00 \%$ PBP recorded the highest $(\mathrm{P}<0.05)$

Table (4): Effect of dietary pomegranate by-product supplementation on digestibility and nutritive value of experimental rabbit diets.

\begin{tabular}{|c|c|c|c|c|c|}
\hline \multirow[b]{2}{*}{ Item } & \multicolumn{5}{|c|}{ Experimental diets (\%) } \\
\hline & $\begin{array}{c}0.0 \\
\text { Control }\end{array}$ & $\begin{array}{c}1.0 \\
\text { PBP }\end{array}$ & $\begin{array}{c}1.5 \\
\text { PBP }\end{array}$ & $\begin{array}{c}2.0 \\
\text { PBP }\end{array}$ & \pm SEM \\
\hline \multicolumn{6}{|c|}{ Digestibility (\%) } \\
\hline $\mathrm{DM}$ & $66.80^{\mathrm{b}}$ & $71.62^{\mathrm{a}}$ & $72.75^{\mathrm{a}}$ & $75.15^{\mathrm{a}}$ & 1.47 \\
\hline $\mathrm{OM}$ & $68.94^{\mathrm{b}}$ & $72.63^{\mathrm{a}}$ & $74.35^{\mathrm{a}}$ & $77.05^{\mathrm{a}}$ & 0.63 \\
\hline $\mathrm{CP}$ & $71.68^{\mathrm{b}}$ & $75.46^{\mathrm{a}}$ & $80.94^{\mathrm{a}}$ & $81.08^{\mathrm{a}}$ & 0.64 \\
\hline $\mathrm{CF}$ & $48.49^{\mathrm{b}}$ & $56.78^{\mathrm{a}}$ & $55.48^{\mathrm{a}}$ & $56.94^{\mathrm{a}}$ & 1.28 \\
\hline $\mathrm{EE}$ & 82.89 & 82.55 & 85.53 & 82.87 & 1.65 \\
\hline NFE & $72.47^{\mathrm{b}}$ & $76.09^{\mathrm{ab}}$ & $76.11^{\mathrm{ab}}$ & $80.05^{\mathrm{a}}$ & 0.71 \\
\hline \multicolumn{6}{|c|}{ Nutritive values } \\
\hline $\mathrm{DCP}(\mathrm{g})$ & $12.32^{\mathrm{b}}$ & $12.99^{\mathrm{b}}$ & $13.94^{\mathrm{a}}$ & $14.02^{\mathrm{a}}$ & 0.28 \\
\hline TDN (\%) & $67.97^{\mathrm{b}}$ & $71.75^{\mathrm{a}}$ & $72.21^{\mathrm{a}}$ & $73.84^{\mathrm{a}}$ & 1.02 \\
\hline $\mathrm{DE}(\mathrm{kcal} / \mathrm{kg})$ & $3011.0^{\mathrm{b}}$ & $3178.58^{a}$ & $3198.78^{a}$ & $3271.10^{\mathrm{a}}$ & 45.01 \\
\hline
\end{tabular}

values of DCP, TDN and DE as compared to the other treatment group.

The results obtained by the in vitro and animal studies confirmed that phenolic compounds of PBP caused the modulation of gut microbiota and has positive effects in terms of gut health protection (Mosele et al., 2015). Several studies have reported that an important part of the ingested phenolic 
compounds reaches the large intestine, where it undergoes series of microbial transformations that leads to the generation of related metabolites (GonzálezBarrio et al., 2010; Mosele et al., 2015).

The radical scavenging activities in both gastric and duodenal phases of in vitro digestion were even higher than those exhibited before being subjected to a simulated digestion, presumably due to the dependency of phenolic activity on $\mathrm{pH}$ of the digestion medium. For instance, high $\mathrm{pH}$ values (alkaline $\mathrm{pH}$ ) have been reported to increase significantly phenolics scavenging ability (Fawole and Opara, 2016).

\section{Carcass characteristics}

The effect of PBP supplementation on the carcass characteristics of the experimental rabbits is shown in Table 5. The obtained results revealed that PBP supplementation in rabbit diet at 1.0, 1.5 and 2.0\% did not significantly affect all carcass traits studied. These results are in agreement with those reported by Ali et al. (2008) who reported that rabbits fed $0.2 \%$ lemon extract did not affect carcass weight, liver, heart, kidney, lungs, stomach, giblets and total edible parts relative to the live body weight. Besides, Hassan et al. (2014) showed that grape seed powder supplementation in rabbit diet at 0.5 , 1.0 and $1.5 \%$ did not significantly affect all of carcass traits studied, except for carcass weight.

Results also, clarify that supplying rabbit diets with PBP reduced significantly $(\mathrm{P}<0.05)$ meat content of $\mathrm{EE}$ as compared to the control group. While, supplying at each tested level of PBP had no effect on meat CP content. It could be also, noticed that meat EE content decreased as supplementation PBP increased from 1.0 up to 2.0\%. The reduction of EE may well be caused by significant amounts of dietary fibre phytochemical components of pomegranate by-product powder.

These results are consistent with Mady et al., (2016) who found that the supplementation of pomegranate peel at 1.5 and $3 \%$ in rabbit diets caused decrease in ether extract of meat. These responses were similar to observation by Ahmed et al. (2015) who stated that 0.5, 1.0 and 2.0 (\%) of pomegranate by-product supplementation reduced cholesterol and saturated fatty acids content in breast meat of broilers. It has also, been shown that the inclusion of natural antioxidant in animal diet not only slow down oxidation, but also greatly improves meat quality when compared to diets without an antioxidant (Brenes et al., 2016). 
IBRAHIM et al.

Table (5): Effect of different experimental diets on Carcass characteristics and meat chemical composition of growing rabbits.

\begin{tabular}{|c|c|c|c|c|c|}
\hline \multicolumn{6}{|c|}{ Experimental diets (\%) } \\
\hline Items & $\begin{array}{c}0.0 \\
\text { Control }\end{array}$ & $\begin{array}{c}1.0 \\
\text { PBP }\end{array}$ & $\begin{array}{c}1.5 \\
\text { PBP } \\
\end{array}$ & $\begin{array}{c}2.0 \\
\text { PBP } \\
\end{array}$ & $\pm \mathrm{SEM}$ \\
\hline \multicolumn{6}{|l|}{ Carcass characteristics } \\
\hline Pre-slaughter weight (g) & 2255.00 & 2240.00 & 2236.66 & 2201.66 & 51.53 \\
\hline Hot carcass weight (g) & 1298.33 & 1315.0 & 1318.33 & 1285.0 & 23.39 \\
\hline Dressing \% & 57.60 & 58.75 & 58.98 & 58.39 & 1.19 \\
\hline Edible Giblets ${ }^{1} \%$ & 3.43 & 3.45 & 3.28 & 3.46 & 0.29 \\
\hline Total edible parts ${ }^{2} \%$ & 61.04 & 62.19 & 62.26 & 61.86 & 1.30 \\
\hline \multicolumn{6}{|c|}{ Meat chemical composition (\%) } \\
\hline $\mathrm{DM}$ & $29.28^{\mathrm{a}}$ & $28.62^{\mathrm{ab}}$ & $28.02^{\mathrm{ab}}$ & $27.38^{\mathrm{b}}$ & 0.49 \\
\hline $\mathrm{CP}$ & 22.04 & 22.41 & 22.95 & 22.92 & 0.47 \\
\hline $\mathrm{EE}$ & $4.68^{\mathrm{a}}$ & $3.74^{\mathrm{ab}}$ & $3.01^{\mathrm{bc}}$ & $2.64^{\mathrm{c}}$ & 0.32 \\
\hline Ash & 2.55 & 2.48 & 2.06 & 1.82 & 0.53 \\
\hline
\end{tabular}

Conversely, results herein disagreed with those reported by Mady et al. (2016) who found that inclusion of pomegranate peel at 1.5 and $3 \%$ in rabbit diets increased $(\mathrm{P}<0.05)$ the content of dry matter and crude protein in rabbit meat. Additionally, Emami et al. (2015) revealed that dietary dried pomegranate seed pulp supplementation of growing Mahabadi goat kids diet up to $150 \mathrm{~g} / \mathrm{kg}$ DM can improve the nutritional and functional properties of meat and pomegranate seed pulp linearly increased $(\mathrm{P}=0.01)$ fat content.

\section{Blood plasma biochemical constituents}

The effects of dietary supplementation of PBP on blood plasma biochemical constituents (Within normal range) are showed in Table 6. The obtained results revealed that the supplementation of PBP increased $(\mathrm{P}<0.05)$ plasma total protein, albumin and globulin levels compared to the control group. There were no significant $(\mathrm{P}>0.05)$ differences in the plasma albumin /globulin ratio among the rabbit groups fed the different treatment levels of PBP and the control group. These results are in harmony with Salim et al. (2014) who stated the rats group fed basal diet supplemented with 5\% freeze dried pomegranate seeds significantly improved total protein. 
Table (6). Effect of pomegranate by-product powder (PBP) on blood plasma biochemical of constituents the experimental growing rabbits.

\begin{tabular}{|c|c|c|c|c|c|}
\hline \multirow[b]{2}{*}{ Items } & \multicolumn{4}{|c|}{ Experimental diets (\%) } & \multirow[b]{2}{*}{$\pm \mathrm{SEM}$} \\
\hline & $\mathbf{0 . 0}$ & $\begin{array}{c}1.0 \\
\text { PBP }\end{array}$ & $\begin{array}{c}1.5 \\
\text { PBP }\end{array}$ & $\begin{array}{c}2.0 \\
\text { PBP }\end{array}$ & \\
\hline Total protein $(\mathrm{g} / \mathrm{dl})$ & $\frac{\text { Control }}{5.36^{\mathrm{d}}}$ & $6.14^{\mathrm{c}}$ & $6.67^{b}$ & $7.18^{\mathrm{a}}$ & 0.13 \\
\hline Albumin (g/dl) & $2.92^{d}$ & $3.18^{\mathrm{c}}$ & $3.55^{\mathrm{b}}$ & $3.81^{\mathrm{a}}$ & 0.02 \\
\hline Globulin (g/dl) & $2.43^{\mathbf{b}}$ & $2.96^{\mathrm{a}}$ & $3.12^{\mathrm{a}}$ & $3.37^{\mathrm{a}}$ & 0.12 \\
\hline Albumin / Globulin ratio & 1.20 & 1.07 & 1.14 & 1.13 & 0.04 \\
\hline Glucose (mg/dl) & $94.16^{\mathrm{a}}$ & $85.52^{b}$ & $80.89^{c}$ & $74.47^{\mathrm{d}}$ & 1.00 \\
\hline Creatinine (mg/dl) & $1.01^{\mathrm{a}}$ & $0.98^{\mathrm{a}}$ & $0.95^{\mathbf{b}}$ & $0.90^{\mathbf{c}}$ & 0.008 \\
\hline Total lipids (mg/dl) & $796.97^{\mathrm{a}}$ & $710.47^{\mathbf{b}}$ & $657.69^{c}$ & $638.08^{\mathrm{c}}$ & 6.12 \\
\hline Total cholesterol (mg/dl) & $114.48^{\mathrm{a}}$ & $99.79^{b}$ & $87.20^{\mathrm{c}}$ & $84.51^{\mathrm{c}}$ & 3.11 \\
\hline $\mathrm{HDL}(\mathrm{mg} / \mathrm{dl})$ & $39.77^{\mathbf{b}}$ & $54.30^{\mathrm{a}}$ & $58.64^{\mathrm{a}}$ & $62.15^{\mathrm{a}}$ & 3.82 \\
\hline LDL (mg/dl) & $50.72^{\mathrm{a}}$ & $44.38^{b}$ & $41.76^{b}$ & $44.88^{b}$ & 1.62 \\
\hline
\end{tabular}

a, b, c Mean values with the same letter within the same row did not differ significantly $(\mathrm{P}>0.05)$.

The concentration of plasma glucose was decreased slightly by increasing the supplemented PBP level from 1.0 to $2.0 \%$ in rabbit diets. On the other hand, there were significant $(\mathrm{P}<0.05)$ differences in the creatinine values among the rabbit groups fed the different tested levels of PBP. Moreover, rabbits fed diet supplemented with PBP at $2.0 \%$ had the lowest level of plasma creatinine compared to the other tested supplemented diets included the control group.

The blood plasma total lipids, total cholesterol and plasma LDL levels were reduced with supplying rabbit diets with PBP at each tested level compared to the control group. Nevertheless, the blood plasma HDL level of rabbits fed the control diet was significantly $(\mathrm{P}<0.05)$ higher than that of the other experimental groups. As shown in Table 6, it could be concluded that polyphenols and flavonoides of PBP had been able to reduce the total lipids, total cholesterol and low density lipoprotein (LDL) concentrations of rabbits. It was demonstrated that dietary antioxidants that protect LDL from oxidation with respect to the concentration of phenolics (Singh et al., 2002).

In this respect, Azoz and Basyony (2012) showed that rabbits fed different levels $(0.5,1.0$ and $1.5 \%)$ of pomegranate waste in diets had significant increase in high density lipoprotein (HDL), cholesterol when comparing with rabbits fed the basal diet (Control). Moreover, all rabbit 
groups had a significant decrease in plasma total cholesterol, low density lipoprotein (LDL) as compared with the control group. However, the present results concerning blood parameters were found within the normal range for the healthy rabbits.

\section{Blood plasma antioxidant constituents}

The effects of different levels of PBP on blood antioxidant constituents of rabbits are presented in Table 7 . A significant decrease $(\mathrm{P}<0.05)$ of plasma MDA was observed in rabbits group fed diets supplemented with PBP compared to the control group. An

Table (7). Effect of pomegranate by-product powder on blood plasma antioxidant constituents of growing rabbits.

\begin{tabular}{|c|c|c|c|c|c|}
\hline \multirow[b]{2}{*}{ Items } & \multicolumn{4}{|c|}{ Experimental diets (\%) } & \multirow[b]{2}{*}{ \pm SEM } \\
\hline & $\begin{array}{c}0.0 \\
\text { Control }\end{array}$ & $\begin{array}{c}1.0 \\
\text { PBP }\end{array}$ & $\begin{array}{c}1.5 \\
\text { PBP }\end{array}$ & $\begin{array}{l}2.0 \\
\text { PBP }\end{array}$ & \\
\hline T-AOC $(\mathrm{mmol} / \mathrm{l})$ & $0.55^{b}$ & $0.93^{b}$ & $1.17^{\mathrm{b}}$ & $3.09^{\mathrm{a}}$ & 0.20 \\
\hline MDA (mmol/l) & $12.88^{\mathrm{a}}$ & $11.07^{\mathbf{b}}$ & $8.71^{\mathrm{c}}$ & $6.78^{\mathrm{d}}$ & 0.33 \\
\hline $\operatorname{SOD}(\mathrm{u} / \mathrm{l})$ & $25.65^{b}$ & $28.61^{\mathbf{b}}$ & $42.17^{\mathbf{a}}$ & $46.87^{\mathrm{a}}$ & 0.30 \\
\hline GSH-Px (u/l) & $0.85^{\mathrm{c}}$ & $1.05^{\mathrm{bc}}$ & $1.15^{\mathrm{b}}$ & $2.65^{\mathrm{a}}$ & 0.08 \\
\hline Catlase $(\mathrm{u} / \mathrm{l})$ & $509.43^{\mathrm{c}}$ & $544.21^{\mathrm{bc}}$ & $641.88^{\mathrm{a}}$ & $632.61^{\text {ab }}$ & 27.79 \\
\hline
\end{tabular}

$\mathbf{a}, \mathbf{b}, \mathbf{c} . .$. Mean values with the same letter within the same row did not differ significantly $(\mathrm{P}>0.05)$.

opposite effect was noticed regarding T-AOC, SOD, CAT and GPx, where the values were significantly $(\mathrm{P}<0.05)$ increased with increasing PBP levels in rabbit diets (Table 7). This result agrees with findings of Rajani et al. (2011) who fed 1-day old male broilers diets contained pomegranate peel at $15 \mathrm{mg} / \mathrm{kg}$ and found that pomegranate peel was the most effective antioxidant. In the study of Fayed et al. (2012), it was noticed that blood plasma total antioxidant capacity (T-AOC) significantly increased with increasing pomegranate peel content for rabbits fed diets supplemented with $0.5,0.1$ and $1.5 \%$ pomegranate peel.

These results confirm that the antioxidant activity of PBP is mainly due to the powerful antioxidants (polyphenols, total phenols, and total flavonoids), which present in high level in pomegranate by-products (seeds and peels) as well as improving the immunity by activation of antioxidant enzymes GSH and GPx (Salim et al., 2014). It seems that the bioavailability of minerals, vitamins and polyphenols in pomegranate by-products may elicit in rabbit beneficial effects which improve rabbit health. The inhibition 
of lipid peroxidation activity of the pomegranate peel is one of the important roles of antioxidants which protect biological membranes of living cells (Manasathien et al., 2012).

\section{Economical evaluation}

The effects of the PBP inclusion on economical efficiency as illustrated in Table (8) indicated an improvement in economical efficiency and net revenue when rabbit diets were supplemented with 1.0, 1.5 and 2.0\% PBP compared to the control diet. Additionally, rabbits fed $1.5 \%$ PBP diet recorded the best net revenue. This improvement may be due to the enhancement of rabbits performance in this group, under Egyptian environmental conditions.

Table (8). Economic efficiency of experimental diets containing pomegranate by-product powder.

\begin{tabular}{|c|c|c|c|c|}
\hline \multirow[b]{2}{*}{ Item } & \multicolumn{4}{|c|}{ Experimental diets (\%) } \\
\hline & $\begin{array}{c}0.0 \\
\text { Control }\end{array}$ & $\begin{array}{c}1.0 \\
\text { PBP }\end{array}$ & $\begin{array}{c}1.5 \\
\text { PBP }\end{array}$ & $\begin{array}{l}2.0 \\
\text { PBP }\end{array}$ \\
\hline Initial weight $(\mathrm{Kg})$ & 0.567 & 0.5665 & 0.568 & 0.567 \\
\hline Final weight (Kg) & 1.988 & 2.0675 & 2.161 & 2.143 \\
\hline Average total weight gain/rabbit $(\mathrm{kg})$ & 1.421 & 1.501 & 1.593 & 1.576 \\
\hline Total revenue /rabbit (LE) ${ }^{1}$ & 39.788 & 42.028 & 44.604 & 44.128 \\
\hline Total feed intake/rabbit $(\mathrm{Kg})^{2}$ & 5.316 & 5.341 & 5.369 & 5.588 \\
\hline Price of feeding/kg (LE) & 3.100 & 3.070 & 3.052 & 3.035 \\
\hline Total feed cost /rabbit (LE) & 16.48 & 16.40 & 16.39 & 16.96 \\
\hline Net revenue/rabbit (LE) & 23.31 & 25.63 & 28.22 & 27.17 \\
\hline Economical efficiency $(\mathrm{EE})^{\mathbf{3}}$ & 1.41 & 1.56 & 1.72 & 1.60 \\
\hline $\begin{array}{l}\text { Relative economical efficiency } \\
(\mathrm{REE})^{4}\end{array}$ & 100 & 110.63 & 121.98 & 113.47 \\
\hline $\begin{array}{l}{ }^{1} \text { Assuming that the price of one } \mathrm{kg} L B W e \\
{ }^{2} \text { According to the price of ingredients ava } \\
{ }^{3} \text { Net revenue/rabbit }=\text { Total revenue } / \mathrm{rabb} \\
{ }^{4} \mathrm{EE}=\text { Net revenue } / \text { Total feed cost } / \mathrm{rabl} \\
{ }^{5} \mathrm{REE}=\text { EE of treatments other than the }\end{array}$ & $\begin{array}{l}\text { l, } 28 \text { L.E. } \\
\text { ble at the } \\
\text { LE) - Tota } \\
\text { LE). } \\
\text { rol/ EE of }\end{array}$ & $\begin{array}{l}\text { imental } t \\
\text { cost / ra }\end{array}$ & & \\
\hline
\end{tabular}

Conclusively, the findings of this study demonstrated that supplementation of PBP in rabbit diets supplemented with1.5\% of PBP caused to improve growth performance and antioxidant status of rabbits. Besides, the pomegranate by-products diets achieved better economical efficiency than the control diet. 


\section{REFERENCES}

Abdel Motaal, A. and Sherif, S. (2011). Anticancer and Antioxidant Activities of

Standardized Whole Fruit, Pulp, and Peel Extracts of Egyptian Pomegranate. Open Conf. Proc. J., 2:41-45.

Aebi, H. (1984). Catalase in vitro. Methods Enzymol., 105:121-126.

Ahmed, S.T.; Islam, Md. M.; Bostami, R. A.B.M. ; Mun, H.S.; Kim,Y.J. and Yang, C.J. (2015). Meat composition, fatty acid profile and oxidative stability of meat from broilers supplemented with pomegranate (Punica granatum L.)by-products. Food Chemistry, 188: 481-488.

Ali, M.A. (2012). Biochemical studies on natural antioxidant. Msc. Thesis, Fac. of Agric., Cairo Univ., Egypt, pp 66-68.

Ali, M.N.; Mahrous, A.A. and Fatma, G. Ahmed (2008). Evaluation of some natural additives as growth enhancers in rabbits diets. Egyptian Journal of Rabbit Science, 18 (1):67-82.

Al-Moraie, M.M.D.; Arafat, R.A. and Al-Rasheedi, A. A. (2013). Effect of Pomegranate Juice on Lipid Profile and Antioxidant Enzymes in Hypercholesterolemic Rats. Life Science Journal,10(3):2717-2728.

AOAC (2007).Association of Official Analytical Chemists. Official Methods Of Analysis. $18^{\text {th }}$ ed.

AOAC (2000). Association of Official Analytical Chemists. Cereal Foods. In AOAC Official Methods of Analysis. 17th ed. Washington, DC, USA.

Azoz, A. A. and Basyony, M. (2012). Influence of supplementation of pomegranate dried waste as of natural antioxidative potential source in feeding does rabbits on some productive and reproductive performance under hot climate condition. Egyptian Journal of Rabbit Science, 22 (1): 23- 39.

Blasco, A. and Ouhayoun, J. (1996). Harmonization of criteria and terminology in rabbit meat research. World Rabbit Sci., 4: 93-99.

Bostami, A.B.M.R.; Ahmed, S.T. ; Islam, M. M.; Mun,H. S.; Ko, S. Y. ; Kim, S. S. and Yang, C. J..(2015). Growth performance, fecal Noxious gas emission and economic efficacy in broilers fed fermented pomegranate byproducts as residue of fruit industry. International Journal of Advanced Research, 3(3): 102-114. 
Brenes, A.; Viveros, A.; Chamorro, S. and Arija, I. (2016). Use of polyphenol rich grape by-products in monogastrc nutrition. A review. Animal Feed Science and Technology, 211:1-17.

Cai, Y.; Luo, Q.; Sun, M. and Corke, H. (2004). Antioxidant Activity and Phenolic Compounds of 112 Traditional Chinese Medicinal Plants Associated with Anticancer. Life Sci., 74:2157-2184.

Cheeke, P.R.; Patton, N.M. and Tempelton, G.S. (1982). Rabbit Production. $5^{\text {th }}$ Edition, Interstate printers and publishers, Inc. Danville II., USA.

Chiu, D.T.Y.; Stults, F.H. and Tappel, A.L. (1976). Purification and properties of rat lung soluble glutathione peroxidase. Biochim Biophys Acta., 445:558-566.

Duncan, D.B. (1955). Multiple Range and Multiple F-Test. Biometrics, 11:1-42. ed. 32, 57-58.

Emami, k.; Nasri, M.H.F.; Ganjkhanloub, M.; Rashidic, L.; Zali, A. (2015). Dietary pomegranate seed pulp increases conjugatedlinoleicand -linolenic acids in muscle and adipose tissues of kid. Animal Feed Science and Technology, 209: 79-89.

Fawole, O. A. and Opara, U. L.(2016). Stability of total phenolic concentration and antioxidant capacity of extracts from pomegranate co-products subjected to in vitro digestion. BMC Complementary and Alternative Medicine, 16: 358-367.

Fayed, A.M.; Azoz, A.A.; Zedan, A. H. and Basyony, M. (2012). Effects of pomegranate peel as antioxidant supplementation on digestibility, blood biochemical and rabbit semen quality. Egyptian J. Nutrition and Feeds, 15 (2): 343-354.

Georgiev, V.; Ananga, A. and Tsolova, V. (2014). Recent advances and uses of grape flavonoids as nutraceuticals. Nutrients, 6, 391-415.

González-Barrio, R.; Borges, G.; Mullen, W. and Crozier, A. (2010). Bioavailability of anthocyanins and ellagitannins following consumption of raspberries by healthy humans and subjects with an ileostomy. J. Agric. Food Chem., 58: 3933-3939.

Hassan, F.A., Mahrose, Kh.M. and Basyony, M.M. (2014). Influence of grape seeds powder as a natural antioxidant on growth performance, antioxidant status and carcass characteristics of rabbits under hot conditions. Paper presented at: the 7th International Conference on 
Rabbit Production in Hot Climate; 2014 Sep 8-12; Marsa Alam, Red Sea, Egypt. p. 395-412.

Kermauner, A. and Laurenčič, A. (2008). Supplementation of rabbit diet with chestnut wood extract: Effect on in vitro gas production from two sources of protein. In Proceedings, 9th World Rabbit Congress. Verona, Italy, Jun 10-13, pp. 689-693.

Koracevic, D.; Koracevic, G.; Djordjevic, V.; Andrejevic, S. and Cosic, V. (2001). Method for the measurement of antioxidant activity in human fluids. Journal of Clin. Pathol., 54:356-361.

Kotsampasi, B.; Christodoulou, V.; Zotos, A.; Liakopoulou-Kyriakides, M.; Goulas, P., Petrotos, K.; Natas, P. and Bampidis, V.A., (2014). Effects of dietary pomegranate byproduct silage supplementation on performance, carcass characteristics and meat quality of growing lambs. Animal Feed Science and Technology, 197: 92-102.

Lampe, J.W. (1999). Health effects of vegetables and fruits: assessing mechanism of action in human experimental studies. American Journal of clinical Nutrition, 70: 475-490.

Lebas, F. (2013). Feeding strategy for small and medium scale rabbit. $3^{\text {rd }}$ Conference of Asian Rabbit Production Association , Bali Indonesia 27-29 August 2013. p1-15.

Li, Y.; Guo, C.; Yang, J.; Wei, J.; Xu, J. and Cheng, S. (2006). Evaluation of antioxidant properties of pomegranate peel extract in comparison with pomegranate pulp extract. Food Chem., 96:254-260.

Mady, M.S.; Tawfeek, F.A.; Attia,Kh.M.; Awadin, N.B. and Abd ElLatif, A.I. (2016). Effect of dietary pomegranate (Punica grantum) peel powder supplentation on growing rabbits performance. Egypt. Poultry Sci., 36: 1031-1047.

Manasathien, J.; Indrapichate, K. and Intarapichet, K.O. (2012). Antioxidant activity and bioefficacy of pomegranate punica granatum linn. peel and seed extracts. Global Journal of Pharmacology, 6 (2): 131-141.

Ministry of Agriculture (2014). Agriculture direction of governorate, Economic affairs sector, Ministry of Agriculture (Summer \& Nili crops), P325.

Misra, H.P. and Fridovich, I. (1972). The role of superoxide anion in the autoxidation of epinephrine and a simple assay for superoxide dismutase. J Biol Chem., 247:3170-3175. 
Modaresi, J.; Fathi Nasri, M.; Rashidi, L.; Dayani, O. and Kebreab, E., (2011). Short communication: effects of supplementation with pomegranate seed pulp onconcentrations of conjugated linoleic acid and punicic acid in goat milk. J. Dairy Sci., 94: 4075-4080.

Mosele, J. I.; Macià, A. and Motilva, M.J. (2015). Metabolic and Microbial Modulation of the Large Intestine Ecosystem by Non-Absorbed Diet Phenolic Compounds: A Review. Molecules, 20: 17429-17468.

Oliveira , R. A.; Narciso, C. D.; Bisinotto, R. S.; Perdomo, M. C.; Ballou, M. A.; Dreher, M. and Santos, J. E. P. (2010). Effects of feeding polyphenols from pomegranate extract on health, growth, nutrient digestion, and immune competence of calves. J. Dairy Sci., 93 :42804291.

Perez, J.M.: Cervera, C.; Falcao-e-Cunha, L.; Maertens, L.; Villamide, M.J. and Xiccato, G. (1995). European ring-test on in vivo determination of digestibility in rabbits: reproducibility of a reference method in comparison with domestic laboratory procedures. World Rabbit Sci., 3: 171-178.

Rajani, J.; Karimi Torshizi, M.A. and Rahimi, Sh. (2011). Control of ascites mortality and improved performance and meat shelf-life in broilers using feed adjuncts with presumed antioxidant activity. Animal Feed Science and Technology, 170: 239-245.

Rowayshed, G.; Salama, A.; Abul-Fadl, M.; Akila-Hamza, S. and Emad, A. Mohamed (2013). Nutritional and chemical evaluation for pomegranate (punica granatum 1.) fruit peel and seeds powders by products. Middle East Journal of Applied Sciences, 3(4): 169-179.

Saki, A.A.; Rabet, M.; Zamani, P. and Yousefi, A. (2014). The Effects of Different Levels of Pomegranate Seed Pulp with Multi-Enzyme on Performance, Egg Quality and Serum Antioxidant in Laying Hens. Iranian Journal of Applied Animal Science, 4(4), 803-808.

Salim, A.; Abou-Arab, A. A. K.; Mohamed, S.R. and Eldesouky, T.A. (2014). Influence of Pomegranate (Punica granatum L.) on Dimethoate Induced Hepatotoxicity in Rats. International Journal of Biological, Biomolecular, Agricultural, Food and Biotechnological Engineering, 8(8): 925-930.

SAS Institute, 2002. STAT User's Guide: Statistics, Version 9.1. Statistical Analysis System Institute, Inc, Cary, NC. 
Schneider, B.H. and Flatt, W.P. (1975). The Evaluation of Feed Through Digestibility Experiments. University of Georgia Experiments. University of Georgia Press Athens, Georgia, USA.423 pp.

Shabtay, A.; Eitam, H.; Tadmor, Y.; Orlov, A.; Meri, A.; Weinberg, P.; Weinberg, Z.G.; Chen, Y.; Izhaki, I. and Kerem. Z. (2008). Nutritive and antioxidative potential of fresh and stored pomegranate industrial by-product as novel beef cattle feed. J. Agric. Food Chem., 56:10063-10070.

Shabtay, A.; Nikbachat, M.; Zenou, A.; Yosef, E.; Arkin, O.; Sneer, O.; Shwimmer, A.; Yaari, A.; Budman, E.; Agmon, G. and Miron, J. (2012). Effects of adding a concentrated pomegranate extract to the ration of lactating cows on performance and udder health parameters. Animal Feed Science and Technology, 175, 24-32.

Singh, R. P.; Murthy, K.N.C. and Jayaprakasha, G.K. (2002). Studies on the antioxidant activity of pomegranate (Punica granatum) peel and seed extracts using in vitro models. J. Agri. Food Chem. 50, 81-86.

Zeweil, H.S. and EL-Gindy, Y.M. (2016). Pomegranate peel as a natural antioxidant enhanced reproductive performance and milk yield of female rabbits. World Rabbit Sci., 24: 207-212.

Zeweil, H.S.; EINagar, S.; Zahran, S.M.; Ahmed, M.H. and El-Gindy, Y. (2013). Pomegranate peel as a natural antioxidant boots bucks fertility under Egyptian summer conditions. World Rabbit Sci., 21:33-39.

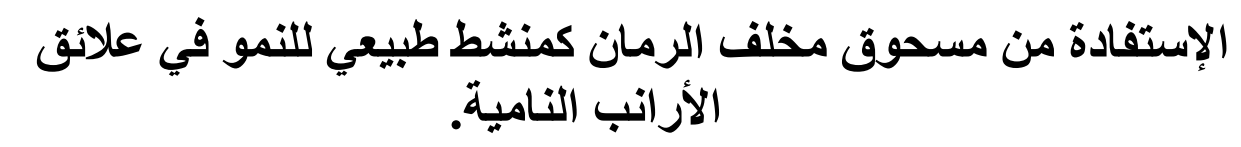

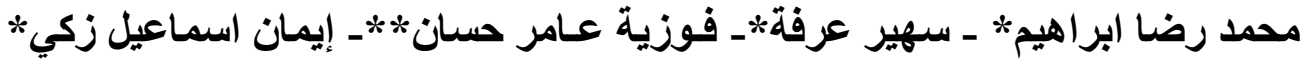

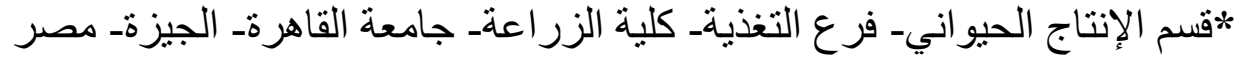

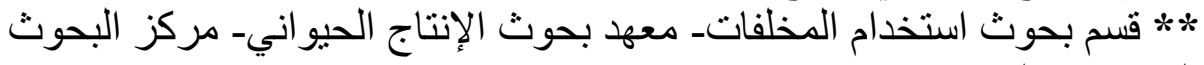

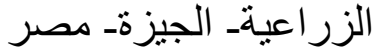

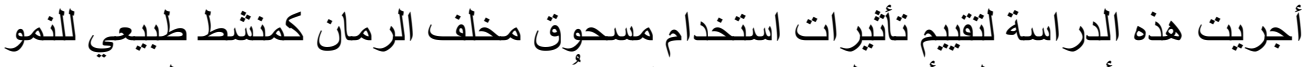
في علائق الأر انب علي أداء النمو. وزع عشو ائياُ عدد 36 ارنب ذكور نيوزلندي ابيض 
إلي أربعه مجمو عات كل مجمو عه بها9 ار انب مقسمة إلي 3 مكرر ات كل مكرر به 3 أر أنب عمر 5 أسابيع حتي عمر عر 13 أسبوع.

وأظهرث النتائج المتحصل عليه البع عيل الأتي:

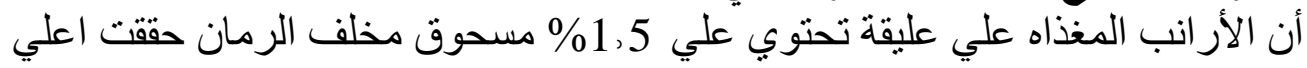

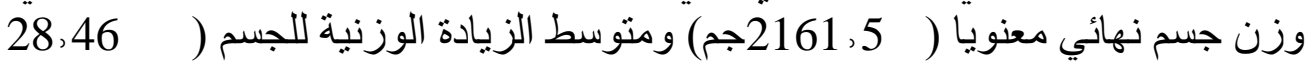

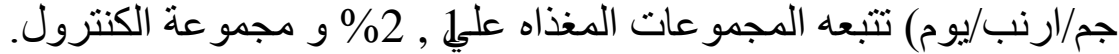

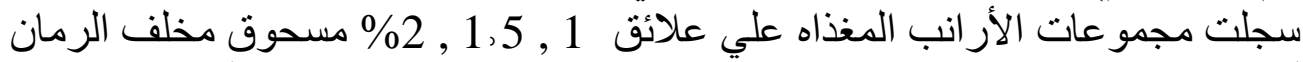

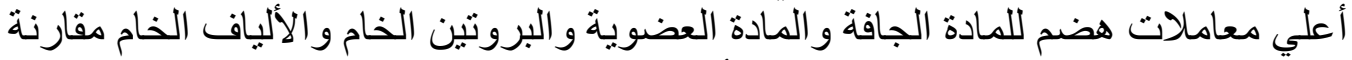

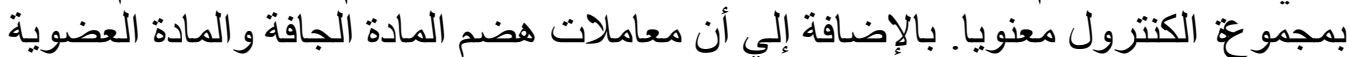

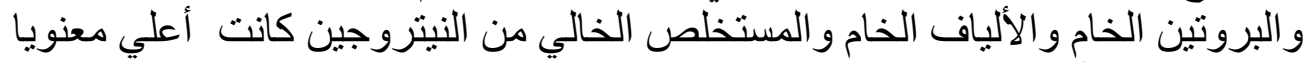

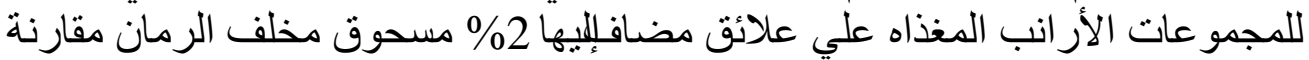

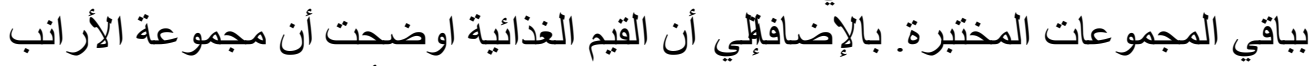
المغذاه علي 1,5 \% 1 \% 2\% مسحوق مخلف الرمان سجلت أعلي قيم غذائية معنويا

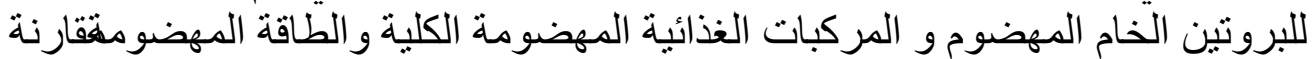
بالمجمو عات الأخري المختبرة

إضافة مسحوق خلف الرمان ليس له تأثنير علي محتوي اللحم من البروتين الخام بينما قلل معنويا من محتوي اللحم من مستخلص الأثير للمجمو عه الأر انب المغذاه علي علي عليقة

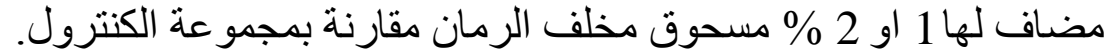
إضافة مسحوق مخلف الرمان زاد معنويا من مستويات البروتين الكلي لبلازما مان الدمام

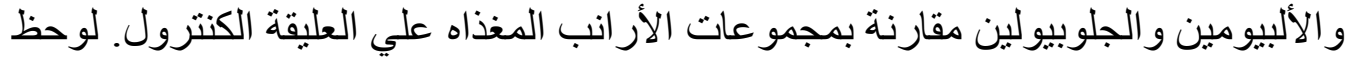

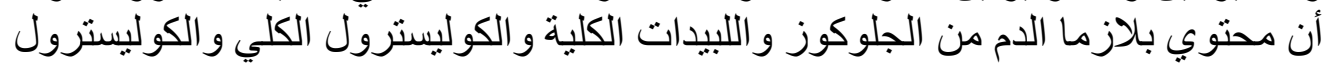
منخفض الكثافة ( LDL) قلت مع زيادة مستويات إضافة مسحوق مخلف الرمان ( \% 1 \% $2,1,5,1)$ و ايضاز ادت معنوياً قيم القدرة التأكسدية الكلية (T-AOC ) و السوبر اوكسديز ديسميوتيز (CAT) و الجلوناثيون بيرو اكسيديز (CSH-PX) مع زيادة مستويات (SOD)

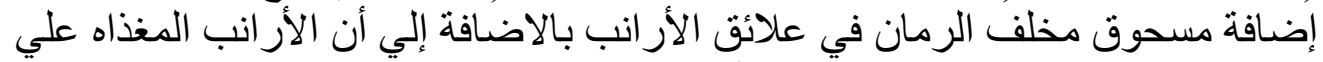
\% 1,5 مسحوق مخلف الرمان سجلت أفضل عائد إقتصادي.

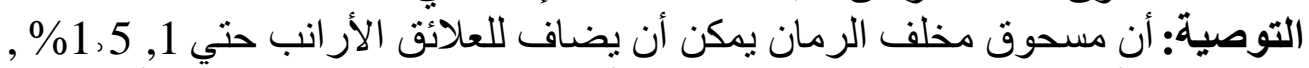
2\% ليحقق أفضل نمو وكفاءة إقتصادية بدون أي تاثير ات سلبية علي صحة الأر انب. 